International Journal of Social Research
(ISSN:2576-5531)

\title{
The Cinematic Space in Stephen Daldry's The Hours: A Heterotopian Perspective
}

\author{
Wenqing Zhao ${ }^{1}$ and I. Murat Öner ${ }^{2}$ \\ ${ }^{1}$ MA Student, International Burch University \\ ${ }^{2}$ Assistant Professor, International Burch University
}

\begin{abstract}
The film The Hours directed by Stephen Daldry is based on an experimental novel in which three women from detached places and eras are interlinked by the book Mrs Dalloway. Given that, its sense of simultaneity and spatial heterogeneity is quite obvious. Adopting the notion of Heterotopia proposed by Michel Foucault, the current paper analyzes the juxtaposed construction of space and time in The Hours. It examines how the editing, recurring imagery and coherent motives in The Hours function in order to construct heterotopian space and to shed light upon central themes such as alienation, sexual identity and death. Through these meticulous filmmaking techniques, the film not only transfers the collapse and confluence of time and space from text to the screen, but also retouches its postmodernist aesthetics and social reflectivity, offering a thought-provoking viewing experience for the audience
\end{abstract}

Keywords: heterotopia, juxtaposition, Michel Foucault, spatiotemporality, montage, imprisonment

*Correspondence to Author: Wenqing Zhao

International Burch University

How to cite this article:

Wenqing Zhao and I. Murat Öner. The Cinematic Space in Stephen Daldry's The Hours: A Heterotopian Perspective. International Journal of Social Research, 2018; 2:16.

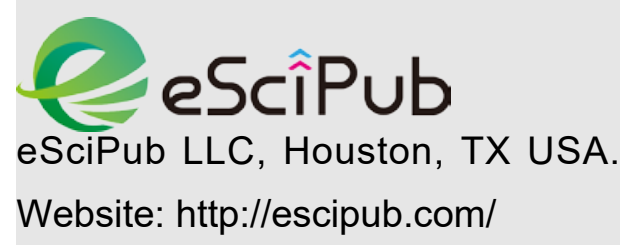




\section{Introduction}

Despite the factual greatness of Pulitzer Prizewinner novel The Hours, one has to admit that it was its film adaptation of the same title that brought the name into a broader audience. Its postmodernist transition from text to the digital images is remarkable enough to serve as a model in the field. For the purpose of being "faithful to the spirit and the intent" of the original, as said by the director Stephen Daldry[1], the film applies meticulous filmmaking techniques, such as montages and recurring imagery, to achieve the embellishment of cinematic aesthetics. As a setting in which three women from detached places and eras being connected by the book Mrs Dalloway, the weight of its simultaneity and spatial heterogeneity is beyond doubt. While most of the readers consider it impossible to be transformed into a film product, Stephen Daldry and his team elegantly completed the conversion of literal spirit onto the screen. This regurgitationfeeding to the text displays the collapse and confluence of time and space to a greater extent, which, thus, constructs "other spaces," which Michel Foucault's terms as "heterotopias"[2], to serve as a container of both introspectiveness and alterity.

\section{Heterotopias: Foucault's Other Spaces}

The concept of heterotopia was put forward by Michel Foucault in his essay "Of Other Spaces," originally named "Des Espaces Autres"[2]. Foucault termed the space in present epoch, the space in which we live in, as the "site" which is defined by assembled relations of points or elements. He claimed that it is a "heterogeneous space"[2], that it "designate[s], mirror[s], or reflect[s]" the relations among all the sites yet in a way to either "suspect" or "neutralize," or even "invent" these relations. ${ }^{[2]}$ What lies among sites then is the otherness, the heterogeneity and the deviation. One type of such interlinked and inter-contradicted sites is utopia which is "fundamentally unreal"[2]. But there is another type of sites which truly exist in perhaps all the real places, which, called by Foucault as "counter-sites," are "effectively enacted utopia[s] [which] are outside of all places, even though it may be possible to indicate their location in reality"[2]. By contrast with utopia, he named it as heterotopia. In order words, heterotopia is depicted by Foucault as a particular spatial formation that disturbs or even subverts the normalcy of conventional social order, an almost all-encompassing term that embraces the conflicts and connections between the unorthodox and the other.

\section{Juxtaposed Structure and Heterochronic Space in The Hours}

Even though the space-time continuum of three stories in The Hours stretches over an entire century and across the AmericanEuropean continent, the theme, i.e., the living dilemma of women of all time, remains still. Such span of time and space is scarcely possible to be displayed within the length of two hours. Apart from the novel Mrs Dalloway which interlinks the three story-lines, it is the construction of juxtaposed and superimposed space and time as well as the juxtaposition and comparison of repetitive imagery that engender the coexistence pattern of three distinct chronotopes.

The Hours speaks no inherent consecutiveness of the film language. It breaks the chapter-based parallel narration in the original novel into further fragmented narration, overlapping the detached spaces along with its functions altogether, whereupon the simultaneity of "incompatible" spaces or "sites" is achieved. [2] Suchlike spatial form is constituted of diffused but at the same time relevant meaningful units, whose significance of course, lies not individually but in the interplay relationship in between. These seemingly ordinary yet in fact life-altering events, or "units," in The Hours occur in one single day, as Virginia Woolf murmuring "a woman's whole life, in a single day. And in that day, her whole life"[3]. The camera moves from 
Wenqing Zhao and I. Murat Öner, IJSR, 2018; 2:16

place to place, from one era to another, from the microscopic life-buying flowers, preparing a party, reading/writing — of one woman to the next. It is in these bitty and subtle crosscutting shots within one day that we easily see their disposition, their depth of spiritual space as Woolf's "beautiful cave"[4], and the metaphor of their whole life.

The insinuating opening scene echoes with the end of the story, where Virginia Woolf drowns herself in the river. Bright beams of light shine over the rapid flowing water with utter darkness tranquilly lying below. This metaphorical prelude paves the way to the upcoming protagonists, establishing the elegiac tone of the rest of the film. As Virginia's body floats in dim waters of the river, being twisted by green-black weed, a series of montage shears come to an end by switching the scene to a bright morning in 1951 Los Angeles. This spanning spatiotemporal conversion in the very beginning reveals the basic structure of the entire film.

Before we look into the main section of the film, it would be a loss not taking notice of the montage shears mentioned above. Before Virginia comes to the river, a set of fragmented scenes of different times are presented simultaneously: the eloquent voice-over reading her farewell letter to her husband Leonard as extradiegetic sound, the close shots of her trembling hand scribbling her letter, Leonard coming back to the house and reading her letter, and her messy, hasty walks to the riverside, filling her pocket with rocks and drowning herself into the river. In this 2:49 minutes' span, the three scenarios are progressively unfolded on the same sphere of time, being smashed into 24 sliced shots by inter-cuttings. Through the realignment and absolute control over time and space, the fracture among detached world disappears, and subliminal significance emerges.

What condense the space and time, apart from these stylistic parallel montages, is the juxtaposition and comparison of repetitive imagery. As Joseph Frank claims, the juxtaposition of dispersed images in a cinematic montage automatically creates a synthesis of meaning betwixt, which supersedes any sense of temporal discontinuity ${ }^{[5]}$. An illustration is that in the scene of her stepping out of the house and Leonard stepping in, the mise-en-scene of the two is all the same, which endows the house with an image implication, carrying the connotative meaning that what she steps out of is her spiritual prison, the heterogeneous space that traps her in, and he into the mundane life.

As an echo of this insinuation, the first scene in Laura's story thread is her husband Dan entering their house with a bouquet in hand. Yet the very first shot in Clarissa's story, before her homosexual partner Sally goes back home, is a subway whirring by. Foucault points out that a train is "a bundle of relations," a means of which "one can go from one point to another" and at the same time it is "something that goes by" [2]. A subway, then, can also be seen as "a place without a place" a heterotopia akin to train, for it perennially steams along its fixed track underground, keeping in touch with every station yet never staying long at anywhere ${ }^{[2]}$. Its sense of confusion and lost often endows it in literature and films with a function of carrying implications of disorientation or confusions. This is one of the main connotative messages to Clarissa Vaughan that, although as a woman inhabiting in contemporary New York, the bias to her sexual identity is relatively decreased her sense of uncertainty, selfcontradiction and guilt still remains.

Such parallel montages and repetitive images exist throughout the film. Three alarms are off at 7 a.m., waking up three women with same position in bed. They tie up their hair in front of mirror in such analogous ways. Virginia and Clarissa gaze themselves through the mirror for a while, with frustrated looks on their gloomy faces. The mirror here also plays as a 
role of heterotopia. In "Of Other Spaces," Foucault states that the mirror serves as a carrier that virtual subjects occupy. When the virtual $I$ in the mirror direct towards the true ego, it is no longer a reflection from the plain glass, but a reconstruction of self. In The Hours, it is through these "placeless places"[2], the mirrors, that our protagonists complete the process of self-construction. Then, Virginia bends down to wash up, followed by a smashcut shot where Clarissa raised up her face after washing. Analogously, Clarissa takes up a vase, and a match-on-action cut changes the locale and time to where Dan takes over a vase and then, as he turns back in front of the camera, the shot shifts to Virginia's servant cleaning up a vase. Apart from its impressive filming style, match cuts allow the transition from one location to another to happen in a single movement, associating each of the spatial-temporal relations together.

As Virginia murmurs "Mrs. Dalloway said she would buy the flowers herself"[3], Laura reads the line in her room and Clarissa speaks it to Sally. Clarissa does go to buy the flowers for the upcoming party herself, yet Laura gets a bouquet from Dan, as an allusion to the lack of the empowerment of women in the middle era of last century. Three places and time which are themselves isolated from each other are therefore converged and juxtaposed. The film itself then functions as a heterotopia akin to Foucault's "library" or "museum," which he claimed as "heterotopias of indefinitely accumulating time," an idea to "enclose in one place all times, all epochs, all forms, all tastes[...]that itself outside of time," an "effectively enacted utopia"[2] that disturbs the continuity of time, compensating audience with eternity and superimposing chronotope. Through the appositional narration and the overlapping cinematic language, what is revealed in between is a holistic, grand picture, where the heterochronic effect, Foucault's term for "slices in time"[2], reverberates in.
Heterogeneous Imprisonment in The Hours

With the vision of heterogeneity, what is exposed in front of exquisite artists or sociologists is, in many cases, alternative perception of space and reality. Stephen Daldry's The Hours, too, pays great attention to the non-mainstream spatial entities and ideology. If there is one thing to make clear, The Hours is a mirror that flashes back women's universal aporia, irrespective of eras and regions. What interlinks three female protagonists is not so much the mere book Mrs Dalloway as their similar sphere of consciousness, the yearning and struggle for their nature, a sort of choice that disturbs the normalcy and sameness of society. Each of the protagonists has a potential homosexual tendency. Instead of normalizing the affection and understandings between the same gender, the film maintains the motif of sexual orientation within the social legitimacy that labels such affection as marginalized, in which way it retains Foucault's "heterotopias of deviation"[2] and attaches characters heavier amount of solitary.

The struggles of protagonists' against social norms is as well one of the main motifs in the film. One common trait of all the main characters, including the three female protagonists and Richard, the marginalized poet, is the consciousness of domination towards their own life. Virginia is suffering from mental illness. For the sake of her health, Leonard takes her away from the metropolitan life to Richmond, a secluded countryside where her routine and whereabouts are strictly constrained. Regulations and "time-table" is seen by Foucault as one of the major disciplines of the "cellular power" of contro[ [6]. For a person sensitive and talented like Virginia yearning for self-determination, for passion and freedom, this peaceful suburb appears to be "suffocating anesthetic" where she "[wrestles] alone in the deep dark"[3] Leonard's caring, then, is more of a heterotopian space that restricts her body 
autonomy and deviates from her own right and will, of the "custody" and "imprisonment" she has to "endure" [3].

Such imprisonment traps Laura as well. This Californian housewife has a kind-hearted husband and a little boy who fairly adores her. Yet being as a mother and leading such a socially admired life is nothing of her nature. "It is, to some extent, an accident of time and place" [7] said by the author of original book. Laura is an introverted but intellectual woman with independent thoughts, meanwhile, a selfcontradicted person who is totally lost between the mainstream value after WWII and her own instincts. She remains to be submissive to her socially ideal life, until she encounters Clarissa Dalloway who she finds as a mirror image to herself: a woman "who's incredibly confident. And maybe because she's confident, everyone thinks she's fine. But she isn't" ${ }^{[3]}$, a woman who will "kill herself over something which doesn't seem to matter" [3]. Such a person is filled with sense of nihility and solitary, which is presented subtly in every shot of her reluctant smile, of her eyes filled with both love and fear every time when she looks at her son. As Foucault said: "the soul is the prison of the body" [8], it is, then, this inherent extraordinariness that eventually captures Laura. Her seemingly actual presence thus enters an illusory and remote heterotopia, where she finds nothing but haziness and agony.

There is one scene where Dan waits for her in bed. Laura in the bathroom keeps a subtle, kind voice, yet which betrays her internal struggle that is only viewed from her eyes by audience. This alienated relation between her spiritual space and her actual living-space turns herself into an entity of a sort of heterotopia which Foucault states as seemingly "pure and simple opening, but that generally hides curious exclusions"[2]. Such an exclusive heterotopia exists along with Virginia as well. The servant Nelly once enters her room and questions about housework while she is writing Mrs Dalloway. Yet clearly, Nelly merely enters the physical space. As for the private space where Virginia's spirit settles, it excludes Nelly completely.

Laura escapes from the birthday party she is preparing for Dan. The first step she takes in order to isolate herself from the frightening mundane life is choosing to drive by herself. She, alone in the car, drives away from where Richard is taken care of. As this sensitive little boy screaming and running after her car, she glanced at rear-view mirror with grimace. The car, akin to Foucault's "boat," is the "greatest reserve of the imagination," a "floating piece of space, a place without a place, that exists by itself, that is closed in on itself and at the same time is given over to the infinity of the sea." Foucault ends his essay by endowing boats with the poetic description of its functions that "[i]n civilizations without boats, dreams dry up, espionage takes the place of adventure, and the police take the place of pirates" [2], which not only expresses his visions, but also his heartfelt yearning and hope for heterotopias. Within this perspective, Laura enters a fluid heterotopia right away, an "other space" [2] not in the sense that it is excluded by the social normalcy, but in a way that it is always somewhere else. During her rapid driving, a parallel montage is switched several times with Richard and his toy blocks. He is playing with a toy car and meanwhile, staring at a house he just built, quietly and with an over-mature, apathetic look on his face. What an adorable and sensible boy, who is, at the same time, the exact heart-breaking source which traps Laura in. Laura changes the lane out of sudden, heading towards a hotel. Echoing with her decision, Richard rampantly breaks the house down.

She finally stops at a hotel. At the time being, all she needs is a hotel room, a fairly obvious heterotopia, an alienated place where she perhaps feels most at home in a sense that she is no longer fettered to any form of social norms, that she can be just herself. She plans 
to finish her reading of Mrs Dalloway, a book which, as her role-player Julianne Moore claims, "she feels excited and alive and in control and in touch"[9], and then, frees herself from this suffocating profane life by taking pills here. "Is there anything else you need?" the receptionist asks, "Yes, not to be disturbed" [3], answered Laura.

Here, the space and time is juxtaposed again through cross-cuttings. While Laura reads the book, Virginia, as if muttering out Laura's consciousness, murmurs the lines, "[...] did it not become consoling to believe that death ended absolutely? It is possible to die" [3]. In this scene, the river that Virginia walks in back in years appears again in the form of metaphor. The water there is not only an image of compressed time mobility, but more a reflection of Virginia's surging agony that she has no control over. Just as she is overwhelmed by her sensitive emotions, her body is overwhelmed by the river. In Laura's story though, the occurrence of river in hotel is presented by a bold hyperreal touch of image. While she lies in bed, the river which took Virginia away back in decades now springs up in a hotel room in Los Angeles in the midtwenty century and inundates this perplexed housewife.

Right after this symbolic montage, the scene is switched to Virginia's face by a jump cut: "I was going to kill my heroine, but l've changed my mind"[3], and transited to Laura again with her sudden deep breath, waking up from the hallucination, touching on her second pregnancy belly and saying "I can't" $\mathrm{t}^{3}[3]$. Although she still feels reluctant, she is certain about her only possible future path. She eventually gives up on killing herself and instead, leaves her family forever as she does later, and bravely embraces her nature as well as her conscience that will remain for the rest of life: "No one's going to forgive me. It was death. I chose life"[3], she said decades later to Clarissa after the poet Richard, who appears to be her abandoned, grown-up son, dies. The two eras thereby folded together, triggering a process of active involvement of audience's reconstruction in the film.

The character Richard Brown is one of the parallel lines between the film and Mrs Dalloway ${ }^{[12]}$. To be explicit, he is the damaged character in the same sense as Septimus Smith and therefore, echoes with Virginia Woolf, too. Akin to Septimus who is internally exiled from ordinary space after enduring years of shell shock, Richard suffers both physically (AIDS) and mentally (being abandoned by mother) in his heterotopian world. Clarissa, a rather allusive name, admires this talented poet who despises worldly issues and truly understands the core of life. She lives as a parasite on Richard, on her dream. Richard understands it all. He knows that even if she feels flurried about her trivial life, she appears to be quite amenable, being the "perfect hostess" as Richard says, "[m]rs. Dalloway, always giving parties, to cover the silence"[3] Deep inside, Clarissa is tangled with happiness from the past which she believes she would never encounter again and feels "being stuck" and "unraveling"[3] since then. Such motif of memory, of the compile and compression of past, future and current moment seems to be eternal in literary works. When one's reminiscence from the past emerges and fuses the present, the sense of time fracture is substituted for the sense of truthfulness for the moment. Piles of such present moments are juxtaposed altogether, and a heterotopian space emerges. Richard sees through what Clarissa is tangled with. He tries to tell her in his own way that life in present is no difference from the most impressive moment in the past, that she should cherish today and live for the current moment by saying "Isn't it strange? Most ordinary morning in anybody's life"[3]. His last words are a bounceback of Virginia's suicide note: "You have been so good to me, Mrs. Dalloway. I don't think two people could've been happier than we've been" ${ }^{[3]}$. After that, he 
lets himself fall off the window, a metaphorical spatial entity which used to constrain him in enclosed space and now sets him free.

Accompanied by Phillip Glass's background music going into climax, the scene is then cut to Dan blowing out the candles on his birthday cake. As Dan kindly saying "This is perfect. It's what I've always wanted"[3] and telling the little Richard their story before marriage, telling him how he managed to survive during the war by the thought of this woman and that how satisfied and happy he is about this family, tears slightly filled up in Laura's eyes. She tries to conceal her desperation therefore she, as always, puts on a decent, remote smile.

The next scene is Clarissa standing against the wall in the Morgue, the heterotopian world where both Richard Brown's body and the embodiment of her past happiness lie in. Foucault considers cemetery as a highly heterotopian place in which one's "permanent lot is dissolution and disappearance"[2]. The Morgue here can be seen as an analogy. The scene in which Laura's family is depicted in a warm hue is cut straight to the Morgue scene with a calm tone and minimalist composition. Such rupturing and contrasting conversion between scenes not only shifts the place and time, but also brings about intense visual impact. While she stands in this solemnity, Leonard's voice arises, asking "why does someone have to die": a J-cut which smoothly transits the scene to Virginia's home and thus lays stress on the merging of two worlds. "Someone has to die in order that the rest of us should value life more," answered Virginia. Leonard asks her who will die. Virginia looks at him with absolute certainty and says, "the poet will die. The visionary"[3]. While the sound of the fireplace in Virginia's house still remains as the background, the close-up shot already moves from Virginia's face to Richard's, this asleep little boy who, years later, falls off the window in order that Clarissa would free herself from the imprisonment of memory and of Richard: an L-cut transition is used to contain the subliminal connotation as well as to extend the continuity of time. Such montage not only reveals a repetition on the characters, but also builds up the weight of converged space and time.

What again interweaves characters across eras is their destiny and self-exile. They are adrift from their eras, from the vulgar life they have to be faced upon. In a sense, they are all "standing outside society, by choice or designated" existing in a "liminal socio-spatial position"[10]. No matter which epoch they live in, the world is filled with disciplinary space, through which the power of society is gained. The subjectivity as a human being is gradually homogenized and distinct voices are silenced. As an attempting resistance to such disciplinary space, "the other space"[2] emerges. It might appear as a form of reluctant memory or as an exotic space which is alienated from the social norms. Suchlike desocialized space brings one back to the primitive self, serving as a temporary shelter and consolation. Yet still, in order to resolve such paradoxical situation, one has to make a final choice. Clarissa is more of Leonard in Virginia's story and Dan in Laura's story, in other words, an imprisonment of others which as well shackles herself. Her choice passively derives from Richard's death. As for the other three main characters, they all made their own choices.

Bitterly, Virginia says to Leonard, "I wish, for your sake, Leonard, I could be happy in this quietness. But if it is a choice between Richmond and death, I choose death"[3]. Death is absolutely one of the main themes throughout the film. Yet the tone of which is nothing of escapism or depression, but of posthumanism and liberalism. The four suicidal acts (if see Laura's escape as an alternative side of death) are not out of the lack of love, but the marginality and alienation that even love cannot compensate with. Sometimes when the essence of life is clearly seen through, the vast nihility then furtively 
approaches, carrying the shadow of death. It is written by Woolf that "how handy a rhyme is to pass us safe over the awkward transition from death to life"[11]. Vice versa. There is no way to comfort or to fulfill a soul under such conditions, except for death itself. The hyperreal mirroring of Woolf's actual life and three Americans living in decades after her era settles a reflection of the universal alienated reality in the world, and meanwhile, burnishes the fluidity of space and time in such an aesthetic matter.

At the end of the film, the three story threads are again converged by protagonists' destiny, and by the last depiction on each of them which reveals their tranquility towards their own choices: the smile from Clarissa, the overwhelmed but relieved face of Laura when she gets a gentle hug from Clarissa's daughter, the soft lighting, the warm atmosphere. As for Virginia, the river that she slowly walks in is shining with glitter, where her voice-over rises again, "always to look life in the face, and to know it for what it is. At last, to love it for what it is, and then to put it away" [3]. There is none of fear to death. It is an embrace of life.

\section{Conclusion}

By adopting Foucault's notion of Heterotopia, the current paper explores the construction of heterotopian space and time in The Hours achieved through its meticulous filmic language, recurring imagery and coherent motives. The film abandons the traditional linear narration, and endows it with poetic aesthetics through juxtaposed formation of space and the fluidity of time. Through this hyperreal mirroring of Woolf's actual life and two story threads in middle era and contemporary America, it settles a reflection of the universal alienated reality of all time. Even though the depiction of isolation, nihility and death is ever present through the film, it is not a work filled with a tone of desperation, but on the contrary, with strong vitality. The film is beyond doubt a tribute to, an exploration of, and an attempting reconstruction of Virginia Woolf, and of the spirit which tells that life is not about abiding by the dualistic judgment of the society, nor about being shackled by each other, but about passion, about love, about striving, about experiencing, about all the hours.

\section{References}

1. Intellect, M. "Director Stephen Daldry Interview on 'The Hours' (2003)". [Video file]. Retrieved from

https://www.youtube.com/watch?v=UNyUvv4Kd8. February 202017.

2. Foucault, M. and Miskowiec, J. "Of Other Spaces". Diacritics, vol. 16, no. 1, 1967, pp.2227.

3. Directed by Stephen Daldry, "The Hours". Paramount Pictures, 2002.

4. Woolf, V. "The Diary of Virginia Woolf", Harcourt Brace, vol. 2, San Diego, 1978, pp. 263.

5. Frank, J. "Spatial Form in Modern Literature: An Essay in Two Parts", the Sewanee Review, vol. 53, no. 2, 1945, pp. 231.

6. Foucault, M, and Alan S. "Discipline and Punish: The Birth of the Prison". Vintage Books, 1977, pp. 149.

7. Spring, J. "Michael Cunningham by Justin Spring". Bomb Magazine, Retrieved from: bombmagazine.org/articles/michaelcunningham/. 1 Jan. 1999,

8. Foucault, M, and Jeremy C. "Religion and Culture", Routledge, 2013, pp. 13.

9. Wolf, Matt. "Holiday Movies: Clarissa Dalloway In a Hall Of Mirrors". The New York Times, 3 Nov. 2002 ,

nytimes.com/2002/11/03/movies/holidaymovies-clarissa-dalloway-in-a-hall-ofmirrors.html.

10. Thormassen, B. "Revisiting Liminality, the Danger of Empty Spaces". Bikent University, 2014, pp. 25.

11. Woolf, V. "Orlando". The University of Adelaide, July, 2015, pp.542.

12. Woolf, V. "Mrs. Dalloway", Harcourt Brace Jovanovich, 1925.

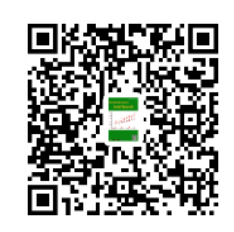

Http://escipub.com/international-journal-of-social-research/ 